International Journal of Current Advanced Research

ISSN: O: 2319-6475, ISSN: P: 2319 - 6505, Impact Factor: SJIF: 5.995

Available Online at www.journalijcar.org

Volume 6; Issue 3; March 2017; Page No. 2717-2718

DOI: http://dx.doi.org/10.24327/ijcar.2017.2718.0086

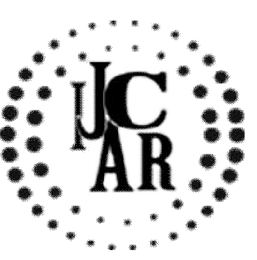

Research Article

\title{
ASSOCIATION OF IRREGULAR EATING HABITS AND OCCURENCE OF PIMPLES IN ADOLESCENTS
}

\author{
Nancy Selva Mary, V
}

Saveetha Dental College and Hospitals, Chennai, India

\section{A R R T I C L E I I N F O}

\section{Article History:}

Received $20^{\text {th }}$ December, 2016

Received in revised form $24^{\text {th }}$ January, 2017

Accepted $6^{\text {th }}$ February, 2017

Published online $28^{\text {th }}$ March, 2017

\section{Key words:}

Eating Habits, Occurence Of pimples in Adolescents

\begin{abstract}
A B S T R A C T
Aim: To study 150 adolescents to create awareness of irregular eating habits and occurrence of pimples.

Methods: $15 \mathrm{O}$ adolescents from different areas of Tamil Nadu which include City, Urban, Rural areas the study involved around 20 questions on various aspects of irregular eating habit, diet and occurrence of pimples in adolescents.

Result and Discussion: The study has focused among adolescents in Tamil nadu. the result shows that the skipping of food may leads to pimples due to lack of protein rich food and continuous irregular diet may lead to loss of calories and decreases in body functions. unbalanced diet may lead to a loss of healthy skin these may cause the major problem for pimples in adolescents.

Conclusion: This study creates awareness among the adolescents due to irregular eating habits leading to pimples.
\end{abstract}

Copyright $₫ 2017$ Nancy Selva Mary, $\boldsymbol{V}$. This is an open access article distributed under the Creative Commons Attribution License, which permits unrestricted use, distribution, and reproduction in any medium, provided the original work is properly cited.

\section{INTRODUCTION}

Adolescents form two - third of population. This is a unique group of people with special needs. Our survey aims to identify the association of irregular eating habits and occurrence of pimples in Adolescents. [9] This group of people and subsequently come up with issues that warrant special attention.Adolescents population and health of adolescents is a very special issue and is focus of attentions globally for various reasons. [2] The world today is home to the largest generation of 12-19 years old in our history and number over one billion and their population is continuously increasing. The demands on young people are new and unprecedented; their parents could not have predicted may of the pressures they face.[1] How we help adolescents meet these demands and equip them with the kind of education, skills and provide good nutrition. The first step towards deepening our understanding is to clarify the concept of adolescence. "Adolescents" and its cognates are variously defined. The lines between childhood, adolescence and adulthood may differ by culture and region. [6] The adolescence are a unique population with specific health concerns and needs. Adolescence is the peak age of onset for serious mental illness like depression and psychosis. Over load of stress from physical, emotional, social and sexual change makes adolescence overloaded with stress which can result in anxiety, withdrawal, aggression, poor coping skills and actual physical illness.

*Corresponding author: Nancy Selva Mary, V Saveetha Dental College and Hospitals, Chennai, India

\section{MATERIALS AND METHODS}

Survey was performed in various schools and colleges of Tamilnadu data collection was done to face-face interview based on a structured. Pre-tested questionnaire Participants included all willing persons between 12-9 years of age.

The study was carried out using a questionnaire based interview. It was conducted in local schools and colleges of Tamilnadu. Tamilnadu is the largest state of India comprising a mixture all major ethnic group. We approach all participants aged 12-19 years. Individual schools, colleges and classes were selected randomly completed the questionnaire in their class rooms. Under the guidance of interviewers and teachers data collections was continued for four weeks during the month of December 2016.

\section{RESULT AND DISSCUSSION}

Most adolescents with lifestyle issues fall in the age group of 16-18 years Females were more depressed than males and had more sleep related problems. Skipping of food in adolescents is $(73 \%)$. Ascending this result skipping of food is highest in adolescence (53\%) are taking more Non-veg. $80 \%$ of Adolescents taking junk foods and $35 \%$ of them like diary products. A total of 150 individuals are approached for their survey in Tamilnadu at different areas of different areas of Tamilnadu which include City, Urban, Rural areas the study involved around 20 questions on various aspects of irregular eating habits, diet and occurrence of pimple in Adolescents. The study was focussed among adolescents in Tamilnadu. The result shows that the skipping of food may leads to 
pimple due to lack of protein rich food and continous irregular diet may lead to loss of calories and decrese in body functions.

Unbalanced diet may lead to loss of healthy skin. This may cause major problems for pimple in adolescents.


\section{CONCLUSION}

This study creates awareness among the adolescence due to irregular eating habits, inadequate sleeps, consumption of more junk foods and diary products may leads to cause of pimples. Adolescent s need to be treated as a distinct segment of our population and it is important to realise and address their health and lifestyle problems. Inadequate sleep, depression and more consumption of junk food were the leading cause for pimples. [5] Families can play an important role to help their adolescents live a healthier life. Further research studies should be carried out to highlight issues of concern and their possible solutions in this population.

\section{Reference}

1. The National longitudinal study of Adolescent Health: study design. (Accessed 2009)

2. Hughes-Hassell S. Rodge P. The Leisure Reading Habits of Urban Adolescents. Journal of Adolescent \& Adult Literacy. 2007;51:22-23.

3. Jae yoon Jung et al. Influence of dietary patterns on acne in vulgaris in Korean

4. K.bhate, h.c.willams et al.epidemiology of vulgaris

5. Rademaker M, Garioch JJ, Simpson NB. Acne in schoolchildren: no longer a concern for dermatologists. Br Med J 1989; 298: 1217-19.

6. Pearl A, Arrol B, Lello J et al. The impact of acne: a study of adolescents' attitudes, perception and knowledge. NZ Med J 1998; 1111: 269-71.

7. Lowe JG. The stigma of acne. Br J Hosp Med 1993; 49: 809-12.

8. Mallon E, Newton JN, Klassen A et al. The quality of life in acne: a comparison with general medical conditions using generic questionnaires. $\mathrm{Br} \quad J$ Dermatol 1999; 140: 672-6.DOI:

9. Kramer T \& Garralda ME. Psychiatric disorders in primary care. Br J Psychiatry 1998; 173: 508-13.

10. Goodman R. The Strengths and Difficulties Questionnaire: a research note. $J$ Child Psychol Psychiatry 1997; 38: 581-6.

11. Burke BM \& Cunliffe WJ. The assessment of acne vulgaris: the Leeds grading technique. Br J Dermatol 1984; 111: 82-93.

12. Kilkenny M, Merlin K, Plunkett A. The prevalence of common skin conditions in Australian school students: 3. Acne vulgaris. Br J Dermatol 1998; 138: 840-5.

\section{Please cite this article in press as:}

Nancy Selva Mary, V (2017), Association of Irregular Eating Habits and Occurence of Pimples in Adolescents, International Journal of Current Advanced Research, 6(3), pp. 2717-2718.

http://dx.doi.org/10.24327/ijcar.2017. 2718.0086 